\title{
Die debat oor selfdegeslagverhoudings: 'n Genuanseerde behoudende benadering
}

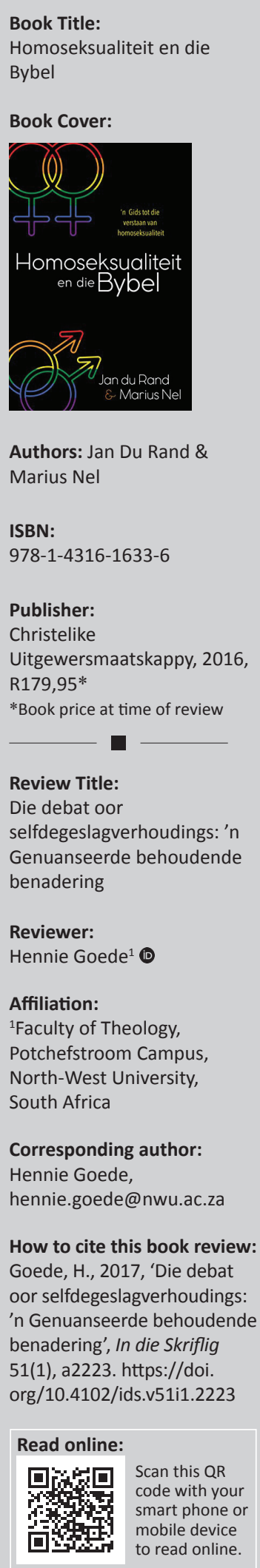

In die lig van die intense kerklike debat rondom selfdegeslagverhoudings, verskyn hierdie publikasie op 'n baie geleë tyd. Dit was sekerlik ook die outeurs en die uitgewer se bedoeling. Die outeurs is goed bekend in teologiese kringe in Suid-Afrika. Prof. Jan du Rand is 'n internasionaalerkende Nuwe-Testamentikus en is steeds akademies aktief, tans as 'n buitengewone professor aan die Fakulteit Teologie van die Noordwes-Universiteit se Potchefstroomkampus. Prof. Marius $\mathrm{Nel}$ is ook aan dieselfde instelling verbonde, en is vir sy talle akademiese en populêre publikasies oor 'n verskeidenheid teologiese onderwerpe bekend. Die besondere onderwerp, op sigself, sal talle potensiële lesers se aandag trek, maar die vraag is sekerlik of hierdie boek werklik 'n bydrae tot die debat lewer, en of dit maar net weer sê wat reeds by herhaling gesê is.

In die voorwoord beskryf die outeurs hulself as behoudende Bybelwetenskaplikes. Hulle verklaar ook hulle vooronderstellings in hulle wetenskapsbeoefening. Hulle 'glo dat die Bybel die Woord van God bevat wat vir gelowiges die grense aandui waarbinne die Here verwag dat ons moet leef' (bl. 7). Hulle soek na die goddelike, vaste waarheid in die Skrif, gelei deur die Gees van God, en staan daarom ...

nugter teenoor ' $n$ postmoderne tydsgees wat redeneer dat waarheid nie ' $n$ vaste sekerheid is nie, maar relatief teenoor elke individu is, en dat elkeen sy/haar eie morele keuses moet maak.

Tog voorsien die outeurs reeds in die voorwoord die aanklag dat hulle fundamentalisties is. Hulle stel duidelik dat hulle nie die Bybel as foutloos of meganies-geïnspireerd beskou nie, maar die historiese situasie en konteks van die Bybelskrywers so deeglik moontlik probeer verstaan. Met hierdie publikasie wil hulle die bybels-verantwoordbare kant van die saak van selfdegeslagverhoudings stel.

Afgesien van die Voorwoord, bestaan die boek uit 11 hoofstukke, afgesluit met eindnotas en 'n literatuurlys vir verdere nalees. In hoofstuk 1 vra die skrywers: 'Kan ons praat van 'n krisis in die kerk?', waarop hulle bevestigend antwoord. Hoofstukke 2 en 3 handel oor die gesag van die Skrif en hoe die Skrif verstaan word. In hierdie hoofstukke verduidelik die outeurs hulle eie standpunt oor die gesag van die Skrif teenoor die siening van Fundamentalisme en Biblisisme. Hulle stel ook die gevare van die verrekening van die sosio-historiese konteks van die teks in die eksegese (die proses om die boodskap van die teks te ontgin). Te midde van die talle verskillende benaderings tot die verstaan van die Skrif (histories-krities, grammatikaal, filosofies, teologies, heilshistories, lesersgeoriënteerd, literêr, postmodern - almal word beskryf en krities beoordeel), kies die skrywers 'n kanonieke benadering tot die teks wat erns met die betekenis van die teks binne die geheelboodskap van die Bybel maak.

Hoofstuk 4 handel oor die Joodse konteks aangaande menslike seksualiteit en die doel van seks, en in hoofstuk 5 word die Ou-Testamentiese tekste wat in die debat oor selfdegeslagverhoudings ter sprake kom, binne hierdie konteks verklaar. Dieselfde patroon word in hoofstukke 6 en 7 met betrekking tot die Nuwe Testament gevolg: eers word die Grieks-Romeinse kultuur met die oog op seksualiteit en homoseksualiteit beskryf en dan volg die verklaring van die relevante NuweTestamentiese tekste in daardie konteks. Hoofstukke 8 en 9 raak twee aspekte van die debat oor selfdegeslagverhoudings aan wat nie direk in die verklaarde tekste hanteer word nie, maar wat tog relevant is, naamlik enkellopendes en selibate asook die Christelike huwelik. Hoofstuk 10 verskaf 'n oorsig oor en kritiese evaluering van die pad wat die Algemene Sinode van die NG Kerk oor homoseksualiteit geloop het; en in hoofstuk 11 word 'n slotwoord van die skrywers aan die kerk en homoseksueles in die kerk gerig.

Vanuit die gestelde vooronderstellings van die outeurs is die resultate van hulle ondersoek nie nuut nie. Die Skrif beskou die homoseksuele daad (eerder as die oriëntasie) konsekwent en 
deurlopend as sonde, maar nie as 'n groter sonde as enige ander sonde nie. In hierdie opsig dra die boek dus nie veel tot die debat by nie. Die bydrae lê veel eerder in die genuanseerde wyse waarop die outeurs met die Bybeltekste in hulle historiese konteks omgaan, en op die argumente ten gunste van 'n pro-gay lees van hierdie tekste antwoord. Waar sommige publikasies met dieselfde vooronderstellings en gevolgtrekkings die saak met 'n byl aanpak, doen Du Rand en Nel dit met 'n skalpel. Hulle aanpak is pastoraal van aard. Dit blyk uit hulle veroordeling van homofobie en diskriminasie op grond van seksuele oriëntasie. Hulle erken deurlopend die noodsaak van nederigheid in die Skrifverstaan rondom hierdie saak, sowel as die voorlopigheid van hulle bevindings. Krities beskou sou sekere aspekte meer aandag kon geniet het, byvoorbeeld die aanklag dat behoudende gelowiges nie konsekwent in hulle Skrifverstaan is nie (sekere prohibisies word nie meer gehandhaaf nie, maar ander soos dié op homoseksuele dade, wel). Hierop sou met duideliker begronding geantwoord kon word. Die outeurs slaag egter uitstekend daarin om die doel van hulle publikasie te bereik, naamlik om die behoudende standpunt oor selfdegeslagverhoudings te stel - 'n standpunt gebaseer op deeglike Skrifondersoek sonder om in die strik van fundamentalisme te trap. Ek beveel die publikasie met groot vrymoedigheid by teoloë en nie-teoloë aan. 